\title{
Effect of corrosive pollutants on Gram Production
}

\author{
Kamal Raj Sapkota \\ Associate Professor \\ Department of Chemistry \\ PN Campus, Pokhara
}

\begin{abstract}
:
Gram is important crop of Nepali and Indian farmers. Most of the people take gram as regular food. There are several edible food products prepared from gram. Gram is cultivated mostly in Birgunj (Parsa), Morang and Terai region. Recently in these states industrialization and infrastructure development work going very fast causing huge amounts of pollutants and particulate entering into the atmosphere. The purpose of this study is to explore the effect of corrosive pollutants on gram production and study tries to find the gaps of $\mathrm{pH}$ in the different areas. Growing urbanization and unplanned activities around the city area and River side have negatively affected the environment.
\end{abstract}

Keywords: acid rain, global warming, Micro electrochemical cell, ozone depletion, pollutants, particulates. etc.

\section{Introduction}

Gram is one of the important food of Indian and Nepali population. Our public have so many basic needs like food, clothe, house, education, hospital, electricity, transport, road, industry and telecommunication. For the completion and these basic needs we do not utilize our natural resources in proper manner. Man creates its own environments. Recently infrastructure development works are growing very fast in several sectors like industry, agriculture, power generation, construction, etc. These sectors have major role in pollution of environment.

Gram is cultivated in the basin of Kosi river and Parsa district. These areas are flooded with industries like chemical, coal, fertilizer, petroleum, refinery, food processing, transport industry, coal power, hydropower, drug industry, pulp and paper industry, paint and dyes, sugar industry, wine industry, water bottling plant, juice factory, milk processing. These industries release huge amount of pollutants (Williamson, 1973) like inorganic, organic and particulates material. Pollutants are oxide of carbon, oxide of nitrogen, oxide of sulphur, oxide of chlorine, chloride ions, ammonia, organic acids and aldehydes whereas particulars like dust, smoke, mist and fog. Particulars are deposited on the surface of gram. Some of these particulars are hygroscopic in nature. They 
absorb pollutants and form acids. These acids in turn develop micro electrochemical cell with flower of gram which destroy flowering of gram. Other factors are acid rain, global warming and depletion of ozone layer affecting the production of gram. They pollute air and that polluted air produces several problems for living and non living things. Inorganic pollutants are oxide of carbon $\left(\mathrm{CO}, \mathrm{CO}_{2}\right)$, oxide of nitrogen $(\mathrm{NO}$, $\left.\mathrm{N}_{2} \mathrm{O}, \mathrm{NO}_{2}\right)$, oxide of sulphur $\left(\mathrm{SO}_{2}, \mathrm{SO}_{3}\right)$, oxide of chlorine, chlorine ion, ammonia and oxide of metals. Organic pollutants are organic acid, aldeyhde, ketone, amine etc. particulates (Crwford, 1976) are dust, smoke, mist, pollen, bacteria and fog. Gram flowering period starts from December to February. particulates are scattered into the atmosphere which are deposited on the surface of gram. Some of these particulates are Hygroscopic (Asthana, 1998) in nature. They absorb moisture from the carbonic acid, nitric acid, sulphuric acid, and hydrochloric acid. These acids are highly corrosive in nature. They create bad environment for gram flowers. The corrosive acid produces micro electrochemical reaction occurs on the surface of gram flowers. In this way flowers of gram get destroyed and conversion of flowers into gram decreases.

\section{Study Area}

Gram production around Narayangadh, Hetaunda and Birjung area were selected. Due to the temperature, soil fertility and other climate factor the the parsa district is suitable place for the Gram production. The researcher feels to determine the parameter like $\mathrm{pH}$ of soil, water and Gram flower by adding in water containing beaker.

\section{Experimental}

\section{Methodology}

For this work certain gram growing areas were selected like Hetaunda, Narayanghadh area and Parsa. The study of the characteristic behaviours of inroganic, organic and particulates pollutants and their effect on gram flowers were done in detail. Monitoring works started during period of December to February. Corrosive gases and their acidic character were determined with the help of Pen types $\mathrm{P}^{\mathrm{H}}$ meter.

\section{Results and Discussion}

The main features of gram depend upon temperature, humidity and nature of surrounding environment during its flowering period. The concentration of corrosive gases, particulate materials and humidity are high so they form $\mathrm{H}_{2} \mathrm{CO}_{3}, \mathrm{HNO}_{3}, \mathrm{H}_{2} \mathrm{SO}_{4}$, $\mathrm{HClO}$ and $\mathrm{HCl}$. These acids produce $\mathrm{H}^{+}$ion that ion starts electrochemical reaction with gram flowers. Due to this reaction flowers connectivity become weaker and finally they are detached with main branch of gram plant. During the formation of acids exothermic reaction occurs and heat is evolved which increases the temperature of surrounding of gram flowers, thus flowers are easily separated from its main branch.

The chemical reactions occur among them are written as:

$$
\begin{aligned}
& \mathrm{CO}_{2+} \mathrm{H}_{2} \mathrm{O} \rightarrow \mathrm{H}_{2} \mathrm{CO}_{3} \\
& 2 \mathrm{NO}+\mathrm{O}_{2} \rightarrow 2 \mathrm{NO}_{2}
\end{aligned}
$$


$4 \mathrm{NO}_{2}+2 \mathrm{H}_{2} \mathrm{O}+\mathrm{O}_{2} \rightarrow 4 \mathrm{HNO}_{3}$

$\mathrm{SO}_{2}+\mathrm{O}_{2} \rightarrow \mathrm{SO}_{3}$

$\mathrm{SO}_{3}+\mathrm{H}_{2} \mathrm{O} \rightarrow \mathrm{H}_{2} \mathrm{SO}_{4}$

$\mathrm{Cl}^{-}+\mathrm{H}_{2} \mathrm{O} \rightarrow \mathrm{HCl}+\mathrm{ClO}^{-}$

The above mentioned acids are dissociated and release $\mathrm{H}^{+}$ion and that ion in the presence of electrolytes develop an electrochemical cell causing oxidation and reduction reactions to start on the surface of gram flowers.

This chemical reaction indicated that corrosive pollutants are corroding the gram flowers. The $\mathrm{P}^{\mathrm{H}}$ value of above mentioned cities are recorded in table 1 and bar graph plots between the $\mathrm{p}^{\mathrm{H}}$ value of corrosive pollutants and its concentrations in different cities. The results of table and fig. shows that the concentrations of $\mathrm{H}^{+}$ion in Birjung city is higher than that of Hetaunda. Likewise the concentration of $\mathrm{H}^{+}$ion in Hetaunda is greater than Narayangadh. Gram crops of these areas are badly affected by pollutants.

$\mathrm{P}^{\mathrm{H}}$ values of corrosive pollutants different cities

Table-1

\begin{tabular}{|c|c|c|c|}
\hline City & Narayangadh & Hetaunda & Birgunj \\
\hline PH & 6.5 & 6.0 & 5.5 \\
\hline
\end{tabular}

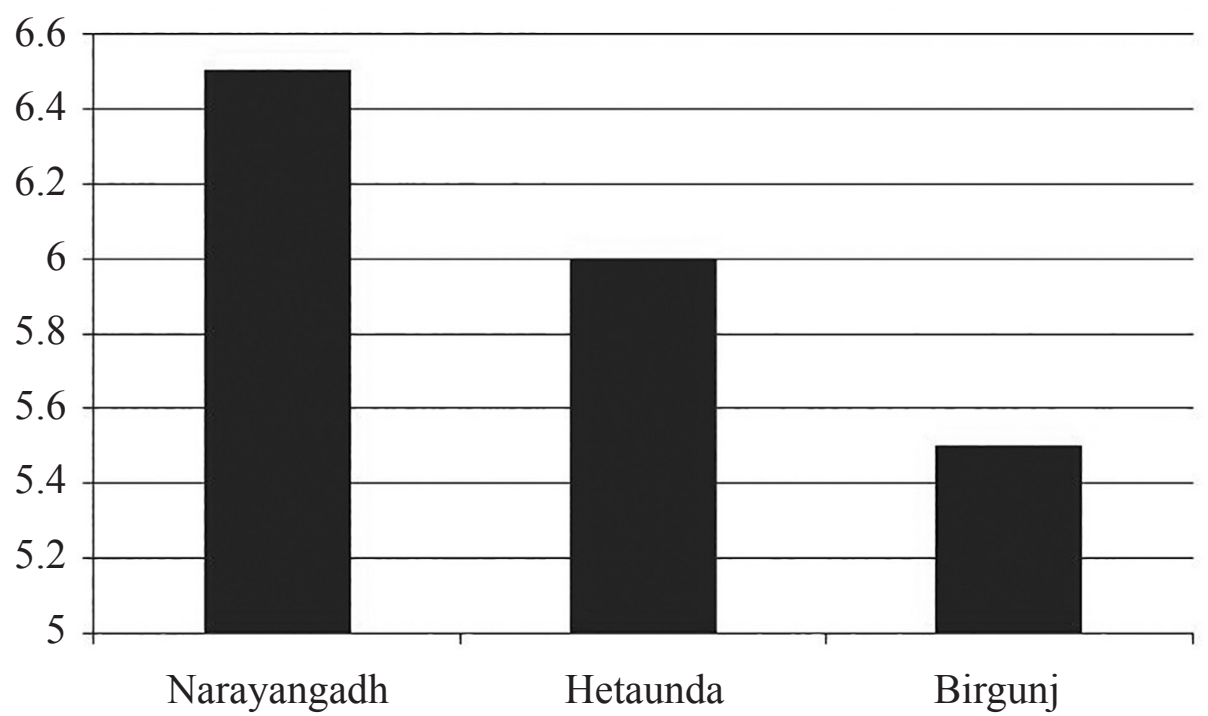

Fig. 1 : Plot between city and $\mathrm{pH}$ values of acids in different cities

The collection of carbon dioxide and methane gases increases in atmosphere due to deforestation, industrialization and human waste decomposition. These gases produce global warming effect thus temperature of atmosphere is increased which exhibits bad effect on the gram flowers. In lower level of atmosphere ozone is formed that ozone also disturbs gram flowers. 
$\mathrm{O}_{2}+\mathrm{UV} \rightarrow 2 \mathrm{O}$

$\mathrm{O}_{2}+\mathrm{O} \rightarrow \mathrm{O}_{3}$

\section{Conclusion}

The environment around the Birgunj city is equally contaminated by intolerable concentration of different pollutants which would be the major factor for attacking to the gram flowers.

Pollutants are very harmful for gram flowers. They decrease its production. If its evolvement is not controlled at proper times, our country will become major loser of gram. It is moral responsibility of the industrialists, scientists, intellectuals, social workers to provide good technology and public awareness against pollution.

\section{Acknowledgment}

The author would like to thank Janapriya Research and Consultancy (JRCC), Janapriya Campus for initializing such kind of academic activity. I would also like to thank all colleague and reviewers who have provided comments on this manuscript.

\section{References}

Abbas Ghassemi (2002). Handbook of pollution Control and waster Minimization Marcel Dekker, Inc;

Asthana. D. K. (1998). Environment problems and solutions S. Chand and co. Ltd; New Delhi,

Crwford, M. (1976). Air pollution Control Theory. McGrow Hill, New York.

David, T. (2003). Green Engineering-Environments Conscious Design of chemical processes Allen and David R. shonnart, prentice Hall.

Manahan, S.E. (1983). Environmental Chemistry, willard Grant Press, Boston

Masters, G.M. (1994). Introduction to Environment Engineering and Science, Prentice Hall, New Delhi,

Murray, J. Mc Ewan and Leon F. Philips (1975). Chemistry of atmosphere, Halsted (Wiley), New York

Nigel J. B., (1991). Environment Chemistry, Wuerz Publishing Ltd. Canada,

Perkins, H.C. (1974). Air pollution. McGraw Hill. New York

Pitts, B.J (1986). Atmosphere Chemistry, Academic Press, Wiley, N. Y

Stern, A.C (1975). Air pollution, Academic press, New York,

Sugdon, T.M. (Ed) (1978). Pathways of pollutants in the atmosphere, the Royal Society, London,

Wayne, R.P (1991). The chemistry of the Atmosphere, Oxford Univ, Press N.Y

Williamson, J. (1973). Fundamentals of Air Pollution. Addison- Wesley, Reading, Mass. 